\title{
RAPD and freezing resistance in Eucalyptus globulus
}

\author{
Marta Fernández R. \\ Centro de Biotecnología \\ Universidad de Concepción \\ Barrio Universitario s/n, Concepción, Chile \\ Tel: 05641207299 \\ Fax: 05641247517 \\ E-mail: martfern@udec.cl \\ Sofía Valenzuela A.* \\ Centro de Biotecnología \\ Facultad de Ciencias Forestales \\ Universidad de Concepción \\ Barrio Universitario s/n, Concepción, Chile \\ Tel: 05641204697 \\ Fax: 05641247517 \\ E-mail: sofvalen@udec.cl \\ Claudio Balocchi L. \\ Bioforest S.A. \\ Camino a Coronel Km15, Concepción, Chile \\ Tel: 056 41-390438 \\ Fax: 05641390439 \\ E-mail: cbalocch@arauco.cl
}

Financial support: INNOVA Biobio Grant 03 B1 210 L1.

Keywords: Eucalyptus globulus, freezing resistance, molecular markers, RAPD.

Eucalyptus globulus is the second most important forest species in Chile, after Pinus radiata. The main advantages of $E$. globulus are its fast growth (25 $\mathrm{m}^{3} / \mathrm{ha} /$ year) and its excellent wood quality for kraft pulp production. On the negative side, its low freezing tolerance has been an obstacle for the expansion of plantations, specifically on the foothills of the Andes. The difference in the freezing resistance between clones of $E$. globulus has a genetic base and, therefore, it could be detected through DNA molecular markers. Fifteen clones of $E$. globulus, eight classified as freezing resistant and seven as freezing sensitive were analyzed using the technique of RAPD, in order to obtain molecular markers that could differentiate between freezing sensitive and resistant clones. Eighteen primers amplified reproducible bands. Three bands were only present in freezing resistant clones, two bands of $768 \mathrm{bp}$, 602 bp obtained with UBC 218 primer and one band of 248 bp obtained with UBC 237 primer. The preliminary results indicate that polymorphism can be observed with the primers employed, but it is not possible to associate the bands with the cold resistance or susceptibility in E. globulus.

Eucalyptus globulus Labill. is an important species for pulp production. This species is planted in countries as Spain, Portugal, Italy, Chile, India, and Australia (Volker and Orme, 1988) and currently it is the subject of many genetic improvement programs (Eldridge et al. 1993; Vaillancourt et al. 1995a; Vaillancourt et al. 1995b; Byrne et al. 1997a; Byrne et al. 1997b; Gion et al. 2000; Moran et al. 2002). The main advantages of this specie are fast growth $(25$ $\mathrm{m}^{3} /$ ha/year) and excellent quality for production of kraft pulp. During the last 20 years the selection, and establishment of E. globulus have received great attention worldwide, among these, efforts have been made to improve cold, salt or drought stresses, since they are the main factors that affect plant growth and development (Turnbull and Eldridge, 1983). This restriction has become an obstacle for the expansion of the plantations in Chile and specifically in the piedmont of the Bio-Bio Region. In cold zones, the species is replaced by E. nitens, a fast growing eucalypt, but with lower pulping properties and therefore it is not attractive for pulp production. The importance of understanding the cold resistance processes, in agricultural and forest crops, has generated a great number of publications (Thomashow, 1998; Gilmour et al. 2000; Hincha et al. 2001; Ukaji et al. 2001; Welling et al. 2002; Pennycooke et al. 2003; Uemura et al. 2003). Most of these studies have focused on describing the frost damage mechanisms at the cellular level, trying to explain the

*Corresponding author 


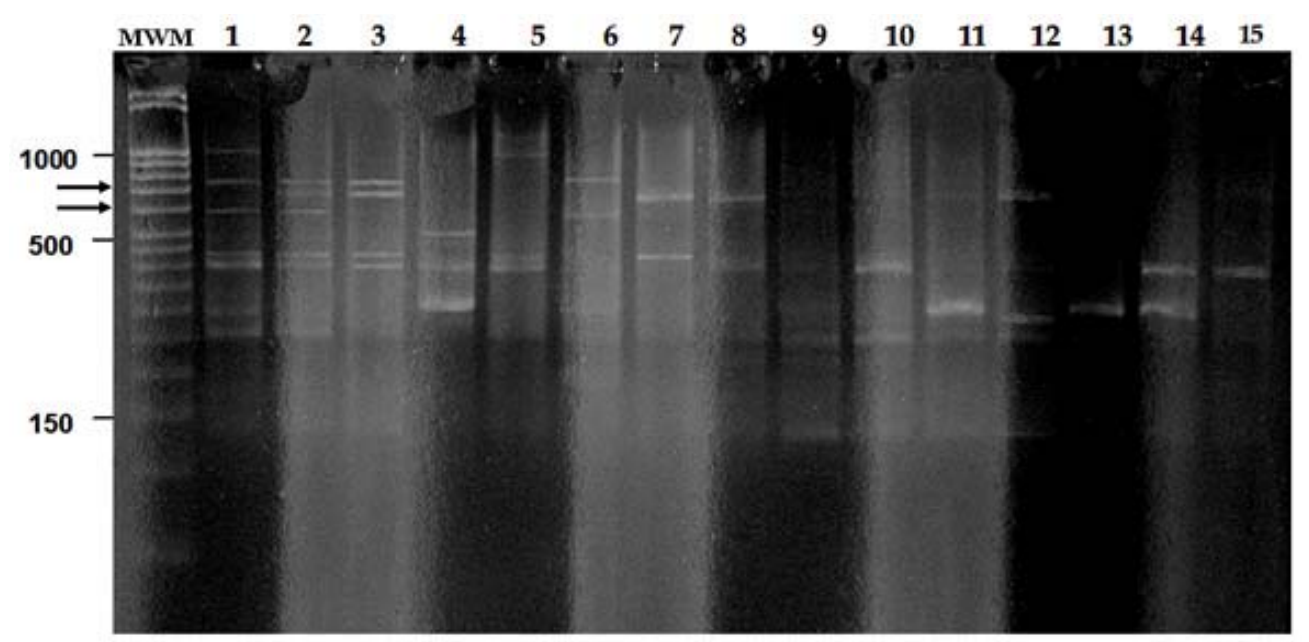

Figure 1. Band pattern of fragments amplified by the technique of RAPD with the UBC primer 218. Freezing resistant clones are shown in lanes 1-8, which correspond to: EG 15, EG 09, EG 09, EG 10, EG 11, EG 12, EG 13 and EG 14, respectively. Freezing sensitive clones are shown in lanes 9-15, wich correspond to: EG 02, EG 04, EG 05, EG 01, EG 03, EG 07, EG 06, respectively.

resistance based on biochemical and physiological changes (Guy, 1990). Molecular studies have demonstrated that the cold acclimatization in plants is complex and it involves several regulation pathways (Fowler and Thomashow, 2002), even more, while some metabolic pathways interact, others are independent.

One practical application of molecular biological techniques in plants is the genetic identification or fingerprinting through molecular markers. The technique of molecular markers is based on the detection of the DNA sequences or combinations that are unique to the individual plant under study (Henry, 1997). The correct identification of individuals or clones is important in operational cultivation and genetic development, since diverse degrees of somaclonal variation have been detected in different species, under in vitro cultivation conditions (Keil and Griffin, 1994; Widen et al. 1994). Consequently, it is

Table 1. Frost damage on E. globulus clones at Canteras trial $\left(37^{\circ} 24^{\prime} \mathrm{S}, 72^{\circ} 01^{\prime} \mathrm{W}\right)$.

\begin{tabular}{|l|c|c|c|c|c|}
\hline Clon & Ramets number & Survivor (\%) & $\begin{array}{c}\text { Buds } \\
\text { damage (\%) }\end{array}$ & $\begin{array}{c}\text { Defoliation } \\
\text { damage (\%) }\end{array}$ & Characteristic \\
\hline EG 01 & 9 & 75 & 97.8 & 26.7 & Sensitive \\
\hline EG 02 & 9 & 75 & 97.8 & 14.4 & Sensitive \\
\hline EG 03 & 11 & 92 & 97.3 & 24.1 & Sensitive \\
\hline EG 04 & 10 & 100 & 96.0 & 11.0 & Sensitive \\
\hline EG 05 & 8 & 89 & 95.0 & 20.6 & Sensitive \\
\hline EG 06 & 10 & 83 & 90.0 & 10.5 & Sensitive \\
\hline EG 07 & 10 & 71 & 89.0 & 18.0 & Sensitive \\
\hline EG 08 & 10 & 100 & 23.0 & 1.0 & Sensitive \\
\hline EG 09 & 12 & 100 & 22.5 & 5.4 & Resistant \\
\hline EG 10 & 11 & 92 & 21.8 & 0.9 & Resistant \\
\hline EG 11 & 11 & 92 & 20.9 & 5.0 & Resistant \\
\hline EG 12 & 8 & 80 & 18.1 & 6.9 & Resistant \\
\hline EG 13 & 8 & 67 & 13.8 & 0.0 & Resistant \\
\hline EG 14 & 12 & 86 & 10.8 & 0.8 & Resistant \\
\hline EG 15 & 8 & 80 & 6.9 & 6.3 & Resistant \\
\hline
\end{tabular}


essential to have a practical and economic way to demonstrate clonal identity and fidelity in different species (Nesbitt et al. 1997). The main advantage of Random Amplified Polymorphic DNAs (RAPDs) over other techniques as isozymes is that they yield abundant polymorphism from mature tree tissue. For Eucalyptus only a relatively small number of polymorphic allozyme are available (Moran and Bell, 1983), therefore markers such as RAPDs could be a good alternative. RAPDs are relative cheap and its development time is minimal compared to other DNA markers (Skabo et al. 1998). PCR technique based on RAPD (Whelsh and McClelland, 1990) allows the detection of multi-locus genetic variations using small primers of arbitrary sequences. Basically a small quantity of tissue is used, from which DNA is extracted. Currently RAPDs in Australia are used as a selection tool for Eucalyptus trees improvement programs (Vaillancourt et al. 1995a; Vaillancourt et al. 1995b; Byrne et al. 1997a; Byrne et al. 1997b).

The cold resistance in Eucalyptus has been broadly studied in diverse countries as France, Canada, Australia and New Zealand (Harwood, 1980; Travert et al. 1997). In these studies, the variations in anthocyanins content and the presence of a whitish waxen layer in young leaves of possibly resistant populations have been observed (Thomas and Barber, 1974), nevertheless, molecular parameters to identify cold resistant individuals in E. globulus have still not been determined. The difference in the freezing resistance in clones of E. globulus has a genetic basis and, therefore, it could be detected through DNA molecular markers. Raymond et al. (1992), using molecular markers detected significant differences in cold resistance for several origins of E. nitens.

The objective of the present study is to evaluate the use of RAPD-PCR molecular markers to identify and differentiate freezing sensitive from freezing resistant $E$. globulus clones.

\section{MATERIALS AND METHODS}

\section{Selection of freezing resistant clones}

Fifteen clones of E. globulus which showed differences in freezing resistance were studied. These clones were selected from a total of 300 clones of E. globulus which were previously tested under field conditions. The clones were planted in 2 cold locations in Canteras $\left(37^{\circ} 24^{\prime} \mathrm{S}, 72^{\circ}\right.$ $\left.01^{\prime} \mathrm{W}\right)$, VIII region, Concepción, Chile, and evaluated during 2 successive seasons. In November 2002, after a winter with field temperature of at least $-5^{\circ} \mathrm{C}$, evaluation due to the frost damage of the clones was carried out. In this assessment, all the trees were scored for survival, buds damage (lateral and apical bud mortality) and defoliation damage (percentage of dead leaves and leaves with at least $50 \%$ of necrotic tissue). The average of these parameters for all the clones used in this study, are shown in Table 1.

\section{Extraction of DNA and RAPD conditions}

Leaves were collected from each clone, frozen in liquid nitrogen and stored at $-80^{\circ} \mathrm{C}$ until their use. DNA extraction was carried out using the Qiagen Kit for plant tissue extraction, DNeasy Plant Mini Kit ${ }^{\mathrm{RT}}$ using $100 \mathrm{mg}$ of fresh leaf tissue. The amplification was carried out in a final volume of $20 \mu \mathrm{L}$, using a Thermal Cycler PX2, containing

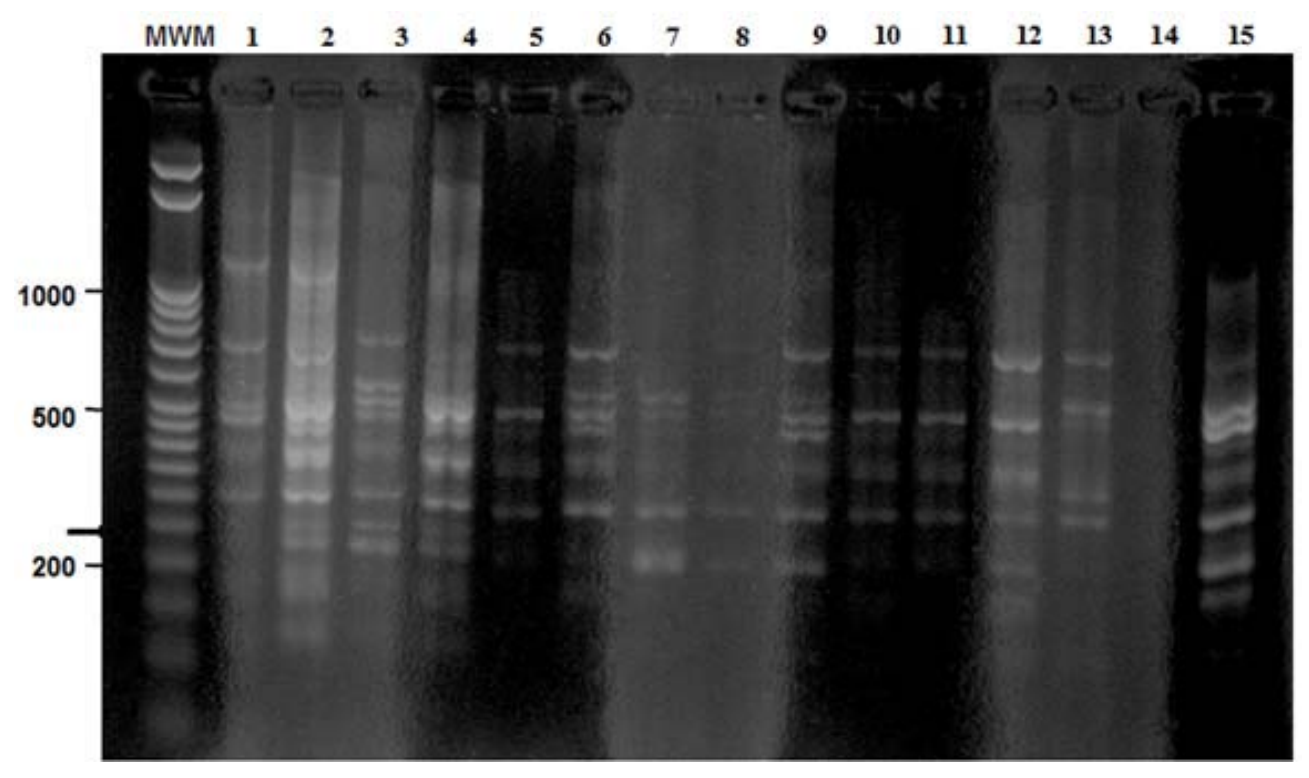

Figure 2. Pattern of bands of the fragments amplified by the technique of RAPD with primer UBC 237. Freezing resistant clones are shown in lanes 1-8, which correspond to: EG 15, EG 09, EG 09, EG 10, EG 11, EG 12, EG 13 and EG 14, respectively. Freezing Sensitive clones are shown in lanes 9-15, which correspond to: EG 02, EG 04, EG 05, EG 01, EG 03, EG 07, EG 06, respectively. 
$200 \mathrm{mM}$ of a mixture of the four dNTPs, $1 \mathrm{X}$ of buffer Taq polymerase, $2.0 \mathrm{mM} \mathrm{MgCl} 2,50 \mathrm{nM}$ of primer, $20 \mathrm{ng}$ of genomic DNA and $1.25 \mathrm{U}$ of Taq polymerase.

The reaction conditions used were the following: an initial step of denaturation at $95^{\circ} \mathrm{C}$ for $6 \mathrm{~min}$, continued by 35 cycles of denaturation $\left(95^{\circ} \mathrm{C}, 1 \mathrm{~min}\right)$, alignment $\left(45^{\circ} \mathrm{C}, 2\right.$ min) and extension $\left(72^{\circ} \mathrm{C}, 1 \mathrm{~min}\right)$ with a terminal extension at $72^{\circ} \mathrm{C}$ for $4 \mathrm{~min}$. Samples were loaded in $1.6 \%$ agarose gel and separated at $60 \mathrm{~V}$ during $2 \mathrm{hrs}$, fragments were visualized by staining with ethidium bromidium and photographed. Twenty primers (Table 2 ) selected by their capacity to generate polymorphic bands in E. globulus, according to that described by Nesbitt et al. (1995) were used to amplify fragments of DNA: OPB 05, OPC 01, OPC 19, OPD 05, OPE 03 OPE 07 OPE 14, OPE 20, OPF 01, OPF 04, UBC 30, UBC 210, UBC 215, UBC 217, UBC 218, UBC 232, UBC 234, UBC 237, UBC 243 and UBC
266. Their sequences were obtained from Operon Technologies Inc. (10000 Atlantic Ave., Boulevard CA 94501 USES) and the series UBC from the University of British Columbia (6174 University Boulevard, Vancouver, B.C. V6T 1Z3). The primers were acquired from the Centro de Síntesis y Análisis de Biomoléculas of the Universidad de Chile (1027 Independencia Ave., Santiago, Chile). Only primers UBC 234 and UBC 266 did not generate a pattern of reproducible bands. The resulting bands were evaluated in a binary range of scale from 0 to 1 , according to the presence or absence of the bands. In case of diffuse or weak bands, or in some regions of the gel where they had a variable intensity, they were not considered and the sample was replicated. The primers that presented only in three or more clones polymorphic bands in frost resistant or freezing sensitive clones were considered as possible marker.

Table 2. List and DNA sequences of the primers used for RAPD-PCR, indicating the number of bands observed.

\begin{tabular}{|c|c|c|c|}
\hline Primer & Sequence & Total number of bands scored & Number of polymorphic bands \\
\hline OPB 05 & $5^{\prime}$ tgcgcccttc $3^{\prime}$ & 10 & 6 \\
\hline OPC 01 & 5' ttcgagccag 3' & 12 & 12 \\
\hline OPC 19 & 5' gttgccagcc 3' & 14 & 9 \\
\hline OPD 05 & 5' tgagcggaca $3^{\prime}$ & 16 & 12 \\
\hline OPE 03 & 5' ccagatgcac 3' & 14 & 12 \\
\hline OPE 07 & 5' agatgcagcc $3^{\prime}$ & 12 & 9 \\
\hline OPE 14 & $5^{\prime}$ tgcggctgag $3^{\prime}$ & 16 & 14 \\
\hline OPE 20 & 5' aacggtgacc $3^{\prime}$ & 13 & 11 \\
\hline OPF 01 & 5' acggatcctg 3' & 11 & 9 \\
\hline OPF 04 & $5^{\prime}$ ggtgatcagg $3^{\prime}$ & 11 & 8 \\
\hline UBC 30 & 5' ccggccttag $3^{\prime}$ & 8 & 8 \\
\hline UBC 210 & 5' gcaccgagag 3' & 13 & 12 \\
\hline UBC 215 & $5^{\prime}$ tcacacgtgc $3^{\prime}$ & 6 & 6 \\
\hline UBC 217 & $5^{\prime}$ acaggtagac $3^{\prime}$ & 6 & 6 \\
\hline UBC 218 & 5' ctcagcccag $3^{\prime}$ & 14 & 12 \\
\hline UBC 232 & $5^{\prime}$ cggtgacatc $3^{\prime}$ & 11 & 8 \\
\hline UBC 234 & $5^{\prime}$ tccacggacg $3^{\prime}$ & 8 & 6 \\
\hline UBC 237 & $5^{\prime}$ cgaccagagc $3^{\prime}$ & 18 & 17 \\
\hline Total & & 213 & 177 \\
\hline
\end{tabular}




\section{RESULTS}

From 20 primers tested, 18 generated appropriate amplification patterns. Of these, only primer UBC 210 generated a high background fluorescence. The number of polymorphic bands obtained varied between 6 (OPB 05 primer) to 18 (UBC 237 primer) (Table 2). A total of 213 reproducible bands were scored, out of which, 177 were polymorphic (Table 2).

Of the fragments amplified with primer UBC 218 (Figure 1), two bands were identified that were selective for some of the freezing resistant clones, and was not observed in none of the sensitive clones tested. A band of $768 \mathrm{bp}$ was observed in samples of clones EG 15, EG 09, EG 08 and EG 12 which correspond to four of the eight frost resistant clones studied. Another band of $602 \mathrm{bp}$ was present in three frost resistant clones studied: EG 15, EG 09 and EG 12 (Figure 1).

One band of $248 \mathrm{bp}$ was identified when using primer UBC 237 in the clones EG 09, EG 08 and EG 10, that is 3 out of the 8 frost resistant clones studied, not being found in the pattern obtained from the frost sensitive clones (Figure 2).

\section{DISCUSSION}

In contrast with other molecular techniques, such as, SNPs, SSRs, RFLP, DNA sequencing and allozymes, the technique of RAPD is very simple to carry out and it does not require previous knowledge of the genome in study. The use of RAPD has been demonstrated to have several advantages over other techniques of DNA 'fingerprinting' and it has been used for the identification of clones (Keil and Griffin, 1994). It allows to examine a large number of loci and primers are made on aleatory sequences. Despite of its advantages this technique has some practical problems, for example reproducibility (Van Oppen et al. 1996; Jones et al. 1997). However, if it is possible to standardize the DNA extraction procedure and find the optimal PCR conditions, the reproducibility of the patterns should not be a problem. In these study, primers OPF 01 and UBC 210 showed a high fluorescence, background, however it was possibile to obtain good reproducibility of the bands.

It is possible that products of different loci can have similar molecular weight and, for this reason, the identification of the bands can be difficult. Rieseberg (1996) analyzed the homology of 220 co-migranting fragments of RAPD in populations of wild sunflowers, he found that $91 \%$ of them turned out to be homologous. Rieseberg (1996) results indicate that fragments of similar size are a good indicator of homology. In our study, a good band separation was obtained. Only when using primer OPF 01, bands of similar molecular weights were obtained. All the primers used in this study, were selected under the approach of having been previously identified for their capability of detecting reproducible polymorphic bands in E. globulus, according to the results found by Nesbitt et al. (1995), after analyzing 140 primers in this specie.

Despite the large number of polymorphic bands found in the 15 clones of E. globulus studied, only primers UBC 218 and UBC 237 generated bands that could be considered as potential markers to identify frost resistant clones. As example, bands of 768, 602 and 248 bp were present in four, three and four of the eight frost resistant clones studied, respectively.

Clones EG 15, EG 09 and EG 12, when amplified with primer UBC 218 showed two polymorphic bands (Figure 1). Comparing these results with those shown in Table 1, it can be observed that clone EG 08 had the largest percentage of damage in the buds $(23,0 \%)$ and clone EG 12 had the largest percentage of defoliation damage (6.9\%).

Primer OPF 01 generated a total of 11 bands, of which 9 were polymorphic and one of these $(880 \mathrm{pb})$, was visualized in all the frost sensitive clones, but also in the frost resistant clone EG 09, therefore it was not considered a selective marker. It is necessary to highlight that this last clone, together with clones EG 08 and EG 10, were classified as freezing resistant (Table 1), although they had the largest percentage of damage in buds and damage for defoliation.

The maximum capacity of a genotype to resist the freezing temperatures is obtained after a hardening process, which is generally reached after the exposure to low temperatures. The hardening capacity to cold will depend on the species in study and of the magnitude of the low temperatures (Alberdi and Corcuera, 1991). The increase of the temperatures during the spring and summer time favors the de-acclimation of the plants, it is for this reason that frosts in the late spring are usually very harmful. Therefore, the dynamics of the acclimation-de-acclimation would be important in the characterization of the genotypes, regarding their frost resistance.

Through the technique of RAPD, which is relatively cheap and requieres small quantities of DNA, it was possible to identify two primers (UBC 218 and UBC 237) that generated polymorphic bands in E. globulus. However due to the small number of clones analysed it can not be concluded that any of the bands could discrimante between freezing tolerant from susceptible clones. Therefore the results obtained must be validated with a larger number of clones and primers.

\section{REFERENCES}

ALBERDI, M. and CORCUERA, L. Cold acclimation in plants. Phytochemistry, 1991, vol. 30, no. 10, p. 3177-3184.

BYRNE, M.; MURRELL, J.C.; OWEN, J.V.; KRIEDEMANN, P.; WILLIAMS, E.R. and MORAN, G.F. Identification and mode of action of quantitative trait loci affecting seedling height and leaf area in Eucalyptus nitens. 
Theoretical and Applied Genetics, 1997a, vol. 94, no. 5, p. 674-681.

BYRNE, M.; MURRELL, J.C.; OWEN, J.V.; WILLIAMS, E.R. and MORAN, G.F. Mapping of quantitative trait loci influencing frost tolerance in Eucalyptus nitens. Theoretical and Applied Genetics, 1997b, vol. 95, no. 5, p. 975-979.

ELDRIDGE, K.; DAVIDSON, J.; HARWOOD, C. and VAN WYK, G. Eucalyptus Domestication and Breading. Oxford University Press. New York. 1993. 312 p. ISBN 019-854866-4.

FOWLER, S. and THOMASHOW, M.F. Arabidopsis transcriptome profiling indicates that multiple regulatory pathways are activated during cold acclimatation in addition to the CBF cold response pathway. Plant Cell, August 2002, vol. 14, no. 8, p. 1675-1690.

GILMOUR, S.J.; SEBOLT, A.M.; SALAZAR, M.P.; EVERARD, J.D. and THOMASHOW, M.F. Over expression of the Arabidopsis CBF3 transcriptional activator mimics multiple biochemical changes associated with cold acclimation. Plant Physiology, December 2000, vol. 124, no. 4, p. 1854-1865.

GION, J.; RECH, P.; GRIMA-PETTENATI, J.; VERHAEGEN, D. and PLOMION, C. Mapping candidate genes in Eucalyptus with emphasis on lignification's genes. Molecular Breeding, February 2000, vol. 6, no. 5, p. 441449.

GUY, C.L. Cold acclimation and freezing stress tolerance: role of protein metabolism. Annual Review of Plant Physiology and Plant Molecular Biology, 1990, vol. 41, no. 1, p.187-223.

HARWOOD, C.E. Frost resistant of sub alpine Eucalyptus species I. Experiments using radiation frost room. Australian Journal of Botany, 1980, vol. 28, no. 6, p. 587599.

HENRY, R.J. Practical Applications of Plant Molecular Biology. Published Chapman \& Hall, 1997. 280 p. ISBN: 041-273220-3.

HINCHA, D.K.; NEUKAMM, B.; SROR, H.A.M.; SIEG, F.; WECKWARTH, W.; RÜCKELS, M.; LULLIENPELLERIN, V.; SCHRÖDER, W. and SCHMITT. J.M. Cabbage cryoprotectin is a member of the non-specific plant lipid transfer protein gene family. Plant Physiology, February 2001, vol. 125, no. 2, p. 835-846.

JONES, C.J.; EDWARDS, K.J.; CASTAGLIONE, S.; WINFIELD, M.O.; SALA, F.; VAN DE WIEL, C.; BREDEMEIJER, G.; VOSMAN, B.; MATTHES, M.; DALY, A.; BRETTSSHNEIDER, R.; BETTINI, P.; BUIATTI, M.; MAESTRI, E.; MALCEVSCHI, A.; MARMIROLI, N.; AERT, R.; VOLCKAERT, G.; RUEDA, J.; LINACERO, R.; VASQUEZ, A. and KARP,
A. Reproducibility testing of RAPD, AFLP and SSR markers in plants by a network of European laboratories. Molecular Breeding, October 1997, vol. 3, no. 5, p. 381390.

KEIL, M. and GRIFFIN, R.A. Use of random amplified polymorphic DNA (RAPD) markers in the discrimination and verification of genotypes in Eucalyptus. Theoretical and Applied Genetics, October 1994, vol. 89, no. 4, p. 442450 .

MORAN, G.F. and BELL, C.J. Eucalyptus. In: TANKSLEY, S.D. and ORTON, T.J. Isozymes in plant genetic and breeding. Amsterdam, Elsevier Science Publishers, 1983. p. 423-441.

MORAN, Gavin F.; THAMARUS, Karen A.; RAYMOND, Carolyn A.; QIU, Deyou; UREN, Tom and SOUTHERTON, Simon G. Genomics of Eucalyptus wood traits. Annals of Forest Science, July-October 2002, vol. 59, no. 5-6 Special Issue, p. 645-650.

NESBITT, K.A.; POTTS, B.M.; VAILLANCOURT, R.E.; WEST, A.K. and REID, J.B. Fingerprinting and pedigree analysis in Eucalyptus globulus using RAPDs. Silvae genetica, 1997, vol. 46, no. 1, p. 6-11.

NESBITT, K.A.; POTTS, B.M.; VAILLANCOURT, R.E.; WEST, A.K. and REID, J.B. Partitioning and distribution of RAPD variation in a forest tree species, Eucalyptus globulus (Myrtaceae). Heredity, 1995, vol. 74, no. 6, p. 628-637.

PENNYCOOKE, J.C.; JONES, M.L. and STUSHNOFF, C. Down-regulating galactosidase enhances freezing tolerance in transgenic petunia. Plant Physiology, October 2003, vol. 133, no. 2, p. 901-909.

RAYMOND, C.A.; OWEN, J.V.; ELDRIGE, K.G. and HARDWOOD, C.E. Screening Eucalyptus for frost tolerance in breeding programs. Canada Journal of Forest Research, 1992, vol. 22, no. 9, p. 1271-1277.

RIESEBERG, L.H. Homology among RAPD fragments in inter-specific comparisons. Molecular Ecology, 1996, vol. 5, no. 1, p. 99-105.

SKABO, S.; VAILLANCOURT, R.E. and POTTS, B.M. Fine-scale genetic structure of Eucalyptus globulus spp. globulus forest revealed by RAPDs. Australian Journal of Botany, January 1998, vol. 46, no. 5, p. 583-594.

THOMAS, D.A. and BARBER, H.N. Studies of leaf characteristics of cline of Eucalyptus urnigera from Mount Willington, Tasmania. I. Water repellence and the freezing of leaves. Australian Journal of Botany, 1974, vol. 22, p. 501-512. 
THOMASHOW, M.F. Role of cold-responsive genes in plant freezing tolerance. Plant Physiology, May 1998, vol. 118 , no. 1, p. 1-7.

TRAVERT, S.; VALERIO, L.; FOURASTÉ, I.; BOUDET, A.M. and TEULIERES, C. Enrichment in specific soluble sugars of two eucalyptus cell-suspension cultures by various treatments enhances their freezing tolerance via a non colligative mechanism. Plant Physiology, April 1997, vol. 114, no. 4, p. 1433-1442.

TURNBULL, J.W. and ELDRIDGE, K.G. The natural environment of Eucalyptus as the basis for selecting frost resistance species. In: Proceedings of IUFRO/AFOCEL symposium on frost resistant Eucalyptus. $\left(26^{\text {th }}\right.$ $30^{\text {th }}$ September, 1983, Bordeaux, France). p. 43-62.

UEMURA, M.; WARREN, G. and STEPONKUS, P.L. Freezing sensitivity in the $s f r 4$ mutant of arabidopsis is due to low sugar content and is manifested by loss of osmotic responsiveness. Plant Physiology, April 2003, vol. 131, no. 4, p. 1800-1807.

UKAJI, N.; KUWABARA, C.; TAKEZAWA, D.; ARAKAWA, K. and FUJIKAWA, S. Cold acclimationinduced WAP27 localized in endoplasmic reticulum in cortical parenchyma cells of mulberry tree was homologous to group 3 late-embryogenesis abundant proteins. Plant Physiology, August 2001, vol. 126, no. 4, p. 1588-1597.

VAN OPPEN, M.J.; KLERK, H.H.; GRAAF, M.; STAM, W.T. and OLSEN, J.L. Assessing the limits of random amplified polymorphic DNAs (RAPDs) in seaweed biogeography. Journal of Phycology, 1996, vol. 32, no. 1, p. 433-444.

VAILLANCOURT, R.E.; POTTS, B.M.; MANSON, A.; ELDRIGE, T. and REID, J.B. Using RAPDs to detect QTLs in an interespecific $\mathrm{F}_{2}$ hybrid of Eucalyptus. In: Eucalyptus plantations: Improving fibre yield and quality. CRCTHF-IUFRO Conference. $\left(19^{\text {th }}-24^{\text {th }}\right.$ February, 1995, Hobart, Australia). CRC for Temperate Hardwood Forestry. Potts, B.M., Borralho, N.M.G., Reid J.B., Cromer R.N., Tibbits, W.N., and Raymond, C.A. eds.,1995a, no. 1, p. 430-431.

VAILLANCOURT, R.E.; POTTS, B.M.; WATSON, M.; VOLKER, P.W.; HODGES, G.; REID, J.B. and WEST, A. Detection and prediction of heterosis in Eucalyptus globulus. Forest Genetics, 1995b, vol. 2, no. 1, p. 11-19.

VOLKER, P. and ORME, K. Provenance trials of Eucalyptus globulus and related species in Tasmania. Australian Forestry, 1988, vol. 51, no. 4, p.257-265.

WELLING, Annikki; MORITZ, Thomas; PALVA, E. Tapio and JUNTTILA, Olavi. Independent activation of cold acclimation by low temperature and short photoperiod in hybrid aspen. Plant Physiology, August 2002, vol. 129, no. 2 , p. 1633-1641.
WELSH, J. and MCCLELLAND, M. Fingerprinting genome using PCR with arbitrary primers. Nucleic Acids Research, December 1990, vol. 18, no. 24, p. 7213-7218.

WIDEN, B.; CRONBERG, N. and WIDEN, M. Genotypic diversity, molecular markers and spatial distribution of genes in clonal plants, a literature survey. Folia Geobotanica \& Phytotaxonomica, 1994, vol. 29, p. 245263. 